\title{
Dispersion and bioaccumulation of elements from an open-pit olivine mine in Southwest Greenland assessed using lichens, seaweeds, mussels and fish
}

\author{
Jens Søndergaard
}

Received: 1 August 2012 / Accepted: 3 January 2013

(C) Springer Science+Business Media Dordrecht 2013

\begin{abstract}
This study investigated dispersion and bioaccumulation of mining-related elements from an open-pit olivine mine at Seqi in Southwest Greenland $\left(64^{\circ} \mathrm{N}\right)$ using lichens (Flavocetraria nivalis), seaweeds (Fucus vesiculosus), mussels (Mytilus edulis) and fish (Myoxocephalus scorpius). The mine operated between 2005 and 2009, and samples were taken every year within a monitoring area $0-17 \mathrm{~km}$ from the mine during the period 2004-2011. A total of 46 elements were analysed in the samples. After mining began, highly elevated metal concentrations, especially nickel $(\mathrm{Ni})$, chromium $(\mathrm{Cr})$, iron $(\mathrm{Fe})$ and cobalt (Co), were observed in lichens relative to pre-mining levels (up to a factor of 130) caused by dust dispersion from the mining activity. Elevated metal concentrations could be measured in lichens in distances up to $\sim 5 \mathrm{~km}$ from the mine/ore treatment facility. Moderately elevated concentrations of $\mathrm{Ni}$ and $\mathrm{Cr}$ (up to a factor of 7) were also observed in seaweeds and mussels but only in close vicinity $(<1 \mathrm{~km})$ to the mine. Analyses of fish showed no significant changes in element composition. After mine closure, the elevated metal concentrations in lichens, seaweeds and mussels decreased markedly, and in 2011, significantly elevated metal
\end{abstract}

J. Søndergaard $(\square)$

Department of Bioscience, Aarhus University,

Frederiksborgvej 399,

DK-4000 Roskilde, Denmark

e-mail: jens@dmu.dk concentrations could only be measured in lichens and only within a distance of $1 \mathrm{~km}$ from the mine.

Keywords Olivine $\cdot$ Mining $\cdot$ Dispersion $\cdot$

Bioaccumulation · Greenland

\section{Introduction}

Dispersion of elements from the mining industry is a well-known environmental concern. Mine-related elements such as metals may pose a threat to the environment due to their bioaccumulation and potential toxicity to biota (Josefson et al. 2008; Torres et al. 2008). Furthermore, dispersion of mine-related elements as dust or as aqueous dissolved or particlebound metals may last for decades after mine closure (Søndergaard et al. 2011a, b; Zimmer et al. 2011). Assessment of element dispersion and bioaccumulation near mines, both in the terrestrial and marine environment, is therefore important to evaluate the mine-related pollution sources and, if needed, to address measures to reduce them.

As biological indicator species: lichens, seaweeds, mussels and sedentary fish such as shorthorn sculpins have been used in a number of studies related to mining activities (Gibb et al. 1996; Johansen et al. 1991; Naeth and Wilkinson 2008). Lichens are extensively used as bio-indicators of terrestrial dust deposition due to their widespread abundance and their ability to accumulate and concentrate elements deposited from the air (Nash 
1996). Seaweeds, mussels and sedentary fish such as shorthorn sculpins accumulate most metals and reflect different bioavailable metal sources within the marine environment (Rainbow 1995). Adjacent to mining activities in Greenland, environmental monitoring programmes typically focus on the above-mentioned four bio-indicators to evaluate the dispersion of elements in the surrounding area (Johansen et al. 2010; Glahder et al. 2010).

In late 2005, a mine was opening at Seqi in Southwest Greenland by the Swedish company Minelco with the purpose of mining the mineral olivine (Fig. 1). Olivine is a low-value industrial mineral primarily used in steel production as slag former, for sand blasting and as foundry sand (Minelco 2012). Besides that, olivine is recognized as a promising cost-effective $\mathrm{CO}_{2}$ sequestration agent, which may help to reduce the anthropogenic impact on climate as olivine is widely abundant, easily extractable and weathers quickly on the earth's surface, storing the $\mathrm{CO}_{2}$ in environmentally safe and stable bicarbonates (Lackner 2003). At the olivine mine at Seqi, a total of 1.7 million tons of olivine were extracted from 2005 to 2009 when the mining was stopped due to economic reasons (BMP 2010).

This study evaluates the spatial and temporal trends of dispersion and bioaccumulation of elements related to the mining activities at Seqi. The study is based on continuous samplings of lichens (Flavocetraria nivalis), seaweeds (Fucus vesiculosus), mussels (Mytilus edulis) and fish (Myoxocephalus scorpius) conducted before, during and after the mining activities from 2004 to 2011. According to the knowledge of the author, this is the first study to evaluate element contamination from olivine mining, and hopefully, it will serve as an important case study for future activities.

\section{Methods and instrumentation}

Study area

The Seqi olivine mine is located in Southwest Greenland in the bottom of the fiord Fiskefjord $\left(64^{\circ} 59^{\prime} \mathrm{N} ; 51^{\circ}\right.$ $33^{\prime} \mathrm{W}$ ), approximately $90 \mathrm{~km}$ north of the capital Nuuk (Fig. 1). The nearest settlement is Atammik situated at the inlet of the fiord, $40 \mathrm{~km}$ southwest of the mine. The climate is low Arctic with average summer temperatures around $5{ }^{\circ} \mathrm{C}$ for July and winter temperatures around
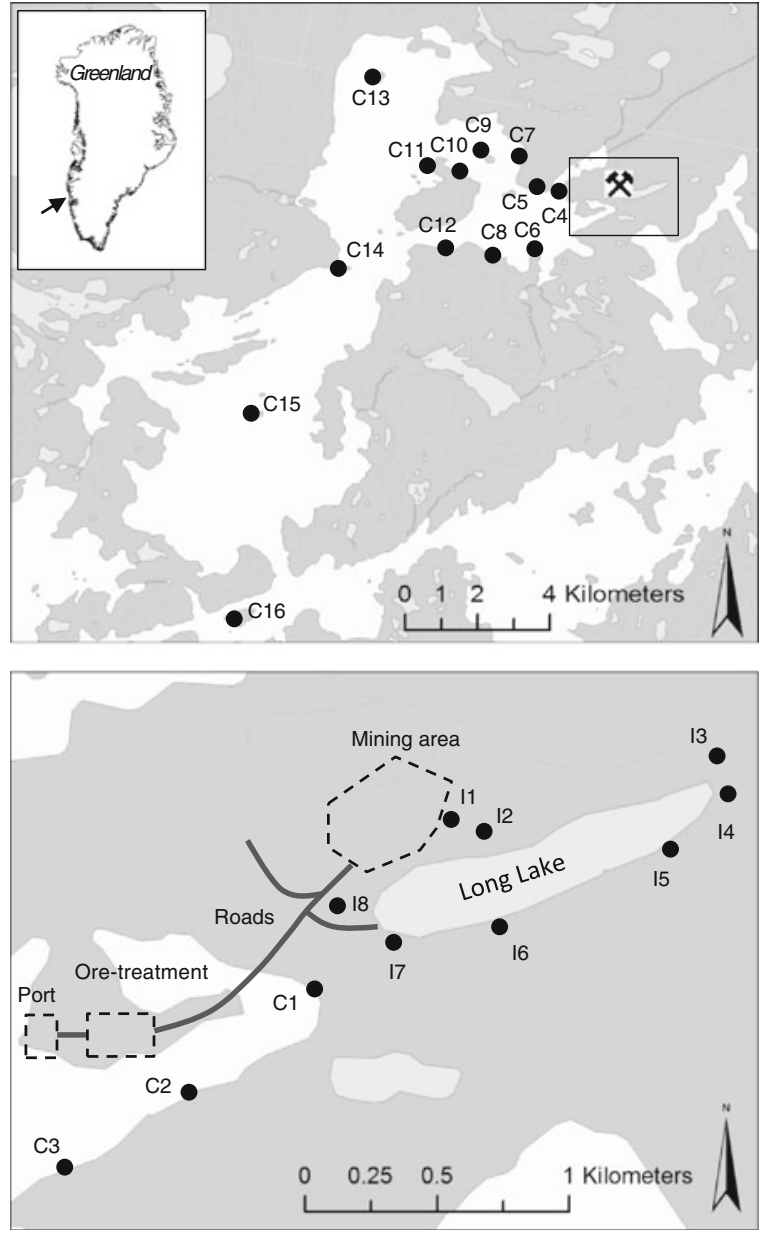

Fig. 1 Location of the Seqi olivine mine in Southwest Greenland $\left(64^{\circ} \mathrm{N}\right)$ with the sampling stations marked. Station $\mathrm{C} 1$ to $\mathrm{C} 16$ are coastal stations (lichens, seaweeds and mussels sampled), and I1 to I8 are inland stations (only lichens sampled). Shorthorn sculpins were sampled at the inner part of the fiord within an area $5 \mathrm{~km}$ from the mine. The lower detailed map shows the location of the open-pit mine, the roads, the ore treatment facility (crushing, sieving and loading of ore) and the port area

$-7{ }^{\circ} \mathrm{C}$ for January (Priestley 2004). Precipitation is moderate, averaging $60 \mathrm{~mm}$ per month during summer and $40 \mathrm{~mm}$ during winter. Winds are predominantly east-north-easterly, and the mine is accessible for ships most of the year due to limited sea ice cover in the fiord. Vegetation in the area is sparse and consists mainly of grasses and low scrub.

Geologically, the Seqi olivine deposit is a dunitetype deposit, and the olivine is contained in igneous, ultramafic rocks (Zuo 2006). The olivine ((Mg, $\mathrm{Fe})_{2} \mathrm{SiO}_{4}$ ) in the deposit is contained in a mixture of 
two minerals, fosterite and fayalite, which are the Mgand Fe-rich end members, respectively. The deposit is characterized by a very homogeneous composition with low variation in the $\mathrm{MgO} / \mathrm{FeO}$ ratio and contains more than $90 \%$ fosterite and less than $8 \%$ fayalite components. The bulk composition of the olivine has an average of more than $48 \% \mathrm{MgO}$, making it ideal for industrial purposes (Zuo 2006). Besides $\mathrm{MgO}$, the olivine contains on average $42 \% \mathrm{SiO}_{2}, 7.9 \% \mathrm{Fe}_{2} \mathrm{O}_{3}$, $0.76 \% \mathrm{Al}_{2} \mathrm{O}_{3}, 0.27 \% \mathrm{Cr}_{2} \mathrm{O}_{3}$ and $0.36 \% \mathrm{NiO}$. The deposit is exposed at the ground surface and was estimated to contain 150 milliontons of olivine prior to the mining operation. Surrounding the deposit are peridotites and gabbro/norites in varying amounts, which could largely be avoided using an open-pit mine type. In late 2005, an open-pit mining operation was initiated. Following excavation, olivine ore was crushed, sieved and sorted according to grade at an ore treatment facility near the port area. Olivine was subsequently stored in piles before being shipped out in bulk carriers. During the period from 2006 to 2009, a total of 1.7 million tons of olivine was produced from the mine, and the largest quantities were produced in 2007 (620,000 tons) and in 2008 (420,000 tons) (BMP 2009). In 2009, the mine was stopped, and a closure plan was initiated in early 2010 (BMP 2010). The location of the open-pit mining area, the roads, the ore treatment facility and the port area can be seen in Fig. 1. After the mining stopped, the area was remediated according to the mine closure plan, and excess olivine situated in piles near the ore treatment facility was removed and placed in the open pit.

To study the environmental impact of the mine operation, an environmental monitoring programme was initiated in 2004 by the former National Environmental Research Institute in Denmark (Asmund et al. 2009), and a number of sampling stations were positioned within an area with a radius of $17 \mathrm{~km}$ from the mine (Fig. 1). This paper contains the most important results from the monitoring programme (Søndergaard et al. 2009; Søndergaard and Asmund 2010).

\section{Sampling}

\section{Lichens}

F. nivalis lichens were sampled at a total of 24 stations in the area around Seqi (Fig. 1). Out of these stations, 16 of the lichen stations were situated at the coastline
(C1-C16), and eight of the stations were located inland near the mine site (I1-8). During the entire period from 2004 to 2011, lichens were sampled every year at all stations except C5, C8-9 and C12, where lichens were only sampled in 2008. In the period from 2004 to 2008, only resident lichens from the stations were collected. From 2009 to 2011, lichens transplanted from an uncontaminated site the previous year were collected at stations C1-4, C6-7 and C10, and I1-8. Transplantation of lichens to selected sites near the mine was done to ensure that any observed changes in element concentrations were due to atmospheric deposition during the last year and not a result of the previous year's depositions and accumulations in the lichens (Søndergaard et al. 2011b).

Resident lichens were collected as bulk samples within an area of $100 \times 100 \mathrm{~m}$ at the sampling stations. Fresh living lichens growing on dead organic matter were selected while lichens growing directly on soil or rocks were excluded. This was done to maximize the probability that elements accumulating in the lichens originated from deposition of particles from the air and not from underlying soil or rocks. Lichens for transplantation were collected near station $\mathrm{C} 16$, located $17 \mathrm{~km}$ from the mine. At the sampling sites, transplanted lichens were placed on the ground on organic matter and covered with a $1 \times 1-\mathrm{cm}-$ mesh nylon net held in place by some flat pieces of rock. This was done to avoid removal of the lichens by the wind. Three $15 \times 15$ patches of lichens were made at each site. The lichen transplants were collected the following years, and new lichens were placed at the same spot. When sampling, lichens were collected in polyethylene bags. Transplanted lichens from the three patches were pooled together as a bulk sample. Later in the laboratory, lichen samples were sorted using stainless steel tweezers, and only the green/yellow thalli were kept and subsequently dried at $60{ }^{\circ} \mathrm{C}$ for $24 \mathrm{~h}$. The weights of the bulk samples of both resident and transplanted lichens after sorting and drying were typically $2-3 \mathrm{~g}$. The lichens were not washed in order to avoid the leaching of soluble substances (Carreras and Pignata 2002).

\section{Seaweeds}

Brown seaweeds ( $F$. vesiculosus) were sampled in the tidal zone directly from shore at all the coastal stations every year between 2004 and 2010. In 
2011, samples were only taken at stations $\mathrm{C} 1-3$ and C15-16. Ten to 15 individual seaweed plants were collected at each site. After sampling, the seaweeds were rinsed three times in clean water, and only the fresh growth tips were kept in order to measure the most recent element uptake. The growth tips were cut from the rest of the plants using stainless steel scissors and kept in polyethylene bags at freezing temperatures until freeze-dried and homogenized to powder in an agate mortar in Denmark prior to the chemical analyses.

\section{Mussels}

Resident blue mussels (M. edulis) were sampled in the tidal zone directly from shore at all the coastal stations every year between 2004 and 2010. In 2011, samples were only taken at stations $\mathrm{C} 1-\mathrm{C} 3$ and $\mathrm{C} 15-\mathrm{C} 16$. After collection, the lengths of the mussels were measured in the laboratory, and mussels were divided into two size classes according to their shell lengths: 4-5 and 5-6 cm. A sample consisting of 20 individual mussels was taken from each size class. The adductors of the mussels were cut using a stainless steel scalpel, and the shells were opened and allowed to drain for a few minutes before the soft parts were removed from the shells. The soft parts of each size group were pooled into a polyethylene bag and frozen before being transported to Denmark. Here, the mussels were freeze-dried and homogenized to powder in an agate mortar prior to the chemical analyses. Sample water content was determined by weighting the samples before and after freeze-drying.

\section{Fish}

Shorthorn sculpins (M. scorpius) were sampled within an area $5 \mathrm{~km}$ from the mine during the period 2004-2010. Shorthorn sculpins were not sampled in 2011. The fish were caught by angling close to shore, and approximately 20 individuals were caught each year. In the laboratory, the fish were measured and weighted, and their sex determined. The livers were then cut out using a stainless steel scalpel, packed in a polyethylene bag and frozen before being sent to Denmark. In Denmark, the dry weight percentages of the samples were determined by drying a $2-3-\mathrm{g}$ subsample in a porcelain crucible at $105{ }^{\circ} \mathrm{C}$ until constant weight.
Chemical analyses

Subsamples of lichens, seaweeds, mussels and fish were taken out for analyses. For lichens, seaweeds and mussels, one to three subsamples of $300 \mathrm{mg}$ (dry weight) were taken from each sample. For shorthorn sculpins, one subsample of $1 \mathrm{~g}$ (wet weight) of the liver was cut out from the inner part of the liver. The subsamples were digested using $4 \mathrm{ml}$ Merck Suprapure $\mathrm{HNO}_{3}$ and $4 \mathrm{ml}$ MilliQ water in Teflon bombs under pressure in a microwave oven (Anton Paar Multiwave 3000). After digestion, solutions were transferred to polyethylene bottles with MilliQ water, and element analyses were performed directly on these solutions using an Agilent 7500ce ICP-MS at the Department of Bioscience, Roskilde, Denmark. The following 46 elements were analysed: Li, Be, Na, Mg, Al, P, K, Ca, Sc, Ti, V, Cr, Mn, Fe, $\mathrm{Ni}, \mathrm{Cu}, \mathrm{Zn}, \mathrm{Ga}, \mathrm{Co}, \mathrm{As}, \mathrm{Se}, \mathrm{Rb}, \mathrm{Sr}, \mathrm{Y}, \mathrm{Zr}, \mathrm{Mo}, \mathrm{Rh}, \mathrm{Pd}$, Ag, Cd, Sn, Sb, Cs, Ba, La, Ce, Nd, Ta, W, Au, Hg, Tl, $\mathrm{Pb}, \mathrm{Bi}$, Th and $\mathrm{U}$. The analytical quality was continuously checked by analysing blanks, duplicates and the certified biological reference materials TORT-2, DORM-3 and DOLT-3 from the National Research Council Canada (www.nrc-cnrc.gc.ca) and BCR-482 from European Commission-Joint Research Centre (www.irmm.jrc.be). Element-specific detections limits were defined as 3 standard deviations (SD) on blank samples. The laboratory at the Department of Bioscience in Roskilde is accredited for analyses of $\mathrm{Ni}, \mathrm{Cr}$, $\mathrm{Cu}, \mathrm{Zn}, \mathrm{As}, \mathrm{Cd}, \mathrm{Hg}$ and $\mathrm{Pb}$ in biota with precisions (2 SD) of 15-20\% and participates biannually in the international laboratory inter-calibration programme QUASIMEME organized by the European Union (www.quasimeme.org).

\section{Data treatment}

Results from elemental analyses of resident and transplanted lichens, seaweeds and fish liver were used directly for comparison of element concentrations between sites and years without further data treatment. For blue mussels, the average of the measured element concentrations for the two size classes, 4-5 and 5$6 \mathrm{~cm}$, were used. Differences in element concentrations in lichens, seaweeds, mussels and fish liver before, during and after the mining started were tested statistically using Microsoft Excel 2010 software. Lichen stations were grouped according to the distances from the mining area/ore crushing facility $(0-1 \mathrm{~km}$ : 
stations $\mathrm{I} 1-8$ and $\mathrm{C} 1-3 ; 1-5 \mathrm{~km}: \mathrm{C} 4, \mathrm{C} 6-7$ and $\mathrm{C} 10)$. A two-sample $t$ test with a significance level of $5 \%$ was used. Prior to the $t$ test, data were tested for equal variances using an $F$ test.

\section{Results and discussion}

Lichens - bioaccumulation of elements related to the mine

Element concentrations in lichens before, during and after the mining period can be seen in Table 1. A total of 46 elements were analysed. After the mining activity started, significantly ( $t$ test; $p<0.05$ ) elevated concentrations of the following elements were observed in lichens relative to pre-mining levels: $\mathrm{Li}, \mathrm{Mg}, \mathrm{Al}, \mathrm{V}, \mathrm{Cr}$, $\mathrm{Fe}, \mathrm{Ni}, \mathrm{Co}, \mathrm{Rb}, \mathrm{Y}, \mathrm{Ag}, \mathrm{Cs}, \mathrm{La}, \mathrm{Ce}, \mathrm{Nd}, \mathrm{Pb}$ and Th. Of these, $\mathrm{Cr}, \mathrm{Ni}, \mathrm{Co}$ and $\mathrm{Fe}$ were especially elevated. Concentrations of $\mathrm{Cr}, \mathrm{Ni}, \mathrm{Co}$ and $\mathrm{Fe}$ in the lichens were observed up to $45,96,4.1$ and $1,720 \mathrm{mgkg}^{-1}$ dry wt., respectively, near the mining area (at St. I1). In contrast, pre-mining concentrations (mean $\pm \mathrm{SD}$ ) of $\mathrm{Cr}, \mathrm{Ni}$, Co and $\mathrm{Fe}$ in lichens were $0.35 \pm 0.36,1.1 \pm 1.7,0.20 \pm 0.19$ and $123 \pm 77 \mathrm{mgkg}^{-1}$ dry wt., respectively. Thus, concentrations of $\mathrm{Cr}, \mathrm{Ni}, \mathrm{Co}$ and $\mathrm{Fe}$ in lichens were elevated by factors up to 130, 87, 21 and 14, respectively. Elements that were above the detection limits but not significantly elevated in the lichens were: $\mathrm{Be}, \mathrm{Na}, \mathrm{P}, \mathrm{K}, \mathrm{Ca}$, $\mathrm{Sc}, \mathrm{Ti}, \mathrm{Mn}, \mathrm{Cu}, \mathrm{Zn}, \mathrm{Ga}, \mathrm{Zr}, \mathrm{Sr}, \mathrm{Cd}$ and $\mathrm{Ba}$. The following elements: As, Se, Mo, Rh, Pd, Sn, Sb, Ta, W, Au, Hg, Tl, $\mathrm{Bi}$ and $\mathrm{U}$ were consistently below the limits of detection. Lichens accumulate particles from the air, and the elevated element concentrations in lichens after the mining started is related to dust dispersal from the mining activities. The results indicate that $\mathrm{Cr}, \mathrm{Ni}, \mathrm{Co}$ and $\mathrm{Fe}$ are the main elements of concern with respect to the mine. The extracted olivine was reported to contain roughly $0.27 \% \mathrm{Cr}_{2} \mathrm{O}_{3}, 0.36 \% \mathrm{NiO}$ and $7.9 \% \mathrm{Fe}_{2} \mathrm{O}_{3}$ (Zuo 2006), and dispersal of these elements as dust is considered to originate directly from mining of the olivine ore. Cobalt and the rest of the elements found in moderately elevated concentrations in the lichens are also likely to origin from the olivine ore, either contained in minor mineral fractions or as mineral impurities. The dominant sources of dust dispersal in the area during the mining period were blasting, excavation and loading of ore material from the mining area, road traffic and ore crushing at the ore treatment facility.
Lichens - spatial and temporal trends

of bioaccumulation and dispersion of elements

Concentrations of elevated elements in resident lichens peaked during the mining period in 2008 (Table 1), and $\mathrm{Cr}$ and $\mathrm{Ni}$ concentrations in lichens at each station versus distance from the mining area or ore treatment facility (the nearest of the two) is shown in Fig. 2. Relations were well described using power functions with negative exponents $\left(r^{2}=0.79-0.83 ; p<0.05\right)$. Dotted horizontal lines mark the upper limit for the $95 \%$ confidence intervals for the pre-mining conditions. No naturally elevated concentrations of $\mathrm{Cr}$ or $\mathrm{Ni}$ were observed near the mining area prior to mining. As shown, elevated concentrations of $\mathrm{Cr}$ and $\mathrm{Ni}$ (above the $95 \%$ confidence lines) were found in resident lichens in 2008 at stations located up to approximately $5 \mathrm{~km}$ from the mine/ore treatment facility.

Figure 3 shows the temporal trends in $\mathrm{Cr}$ and $\mathrm{Ni}$ concentrations in resident and transplanted lichens during the period from 2006 to 2011. Lichen sampling stations are grouped according to distances from the mine/ore treatment facility $(0-1$ and $1-5 \mathrm{~km}$, respectively). From 2006 to 2008, resident lichens from the stations were collected, and from 2009 to 2011, samplings consisted of lichens transplanted from an uncontaminated area to the stations the previous year. The application of lichen transplants was done to evaluate the recent annual dust dispersion as resident $F$. nivalis lichens have been shown to concentrate metals over time and may contain a fraction of the previous year's metal deposition (Søndergaard et al. 2011b). Thus, while results from resident lichens may not reflect the year-to-year variation in dust dispersion and accumulation, results from lichen transplants collected each year are good indicators for that (Søndergaard et al. 2011b). The results shown in Fig. 3 indicate a marked decrease in dust dispersion from when the mining stopped in 2009 and until 2011. In 2011, significantly elevated $\mathrm{Cr}$ and $\mathrm{Ni}$ concentrations were only observed in lichen transplants located within $1 \mathrm{~km}$ from the mine/ore treatment facility.

Seaweeds and mussels

Concentrations of selected elements in seaweeds and blue mussels before, during and after the mining period can be seen in Tables 2 and 3, respectively. For seaweeds, significantly elevated element concentrations $(t$ 


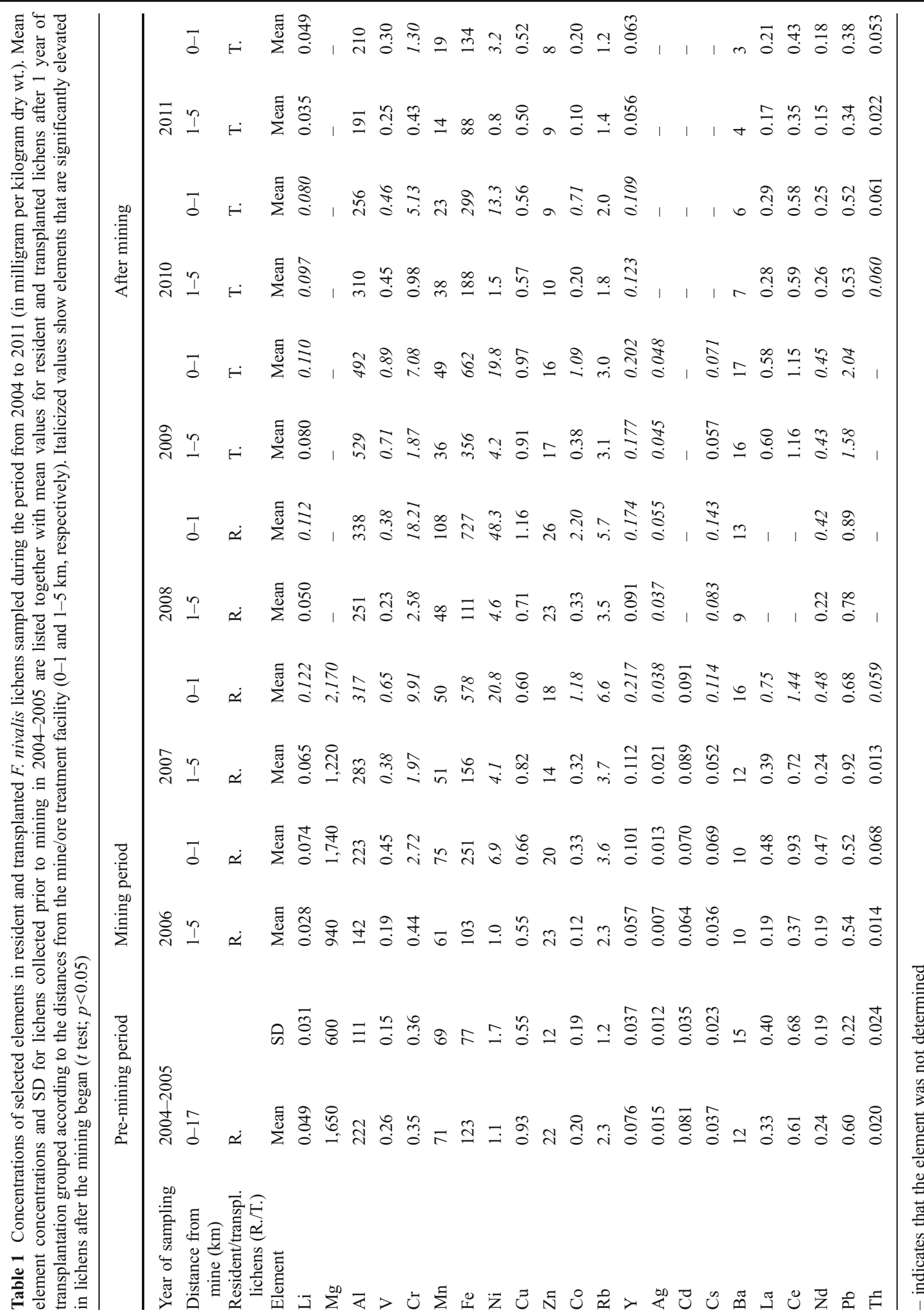



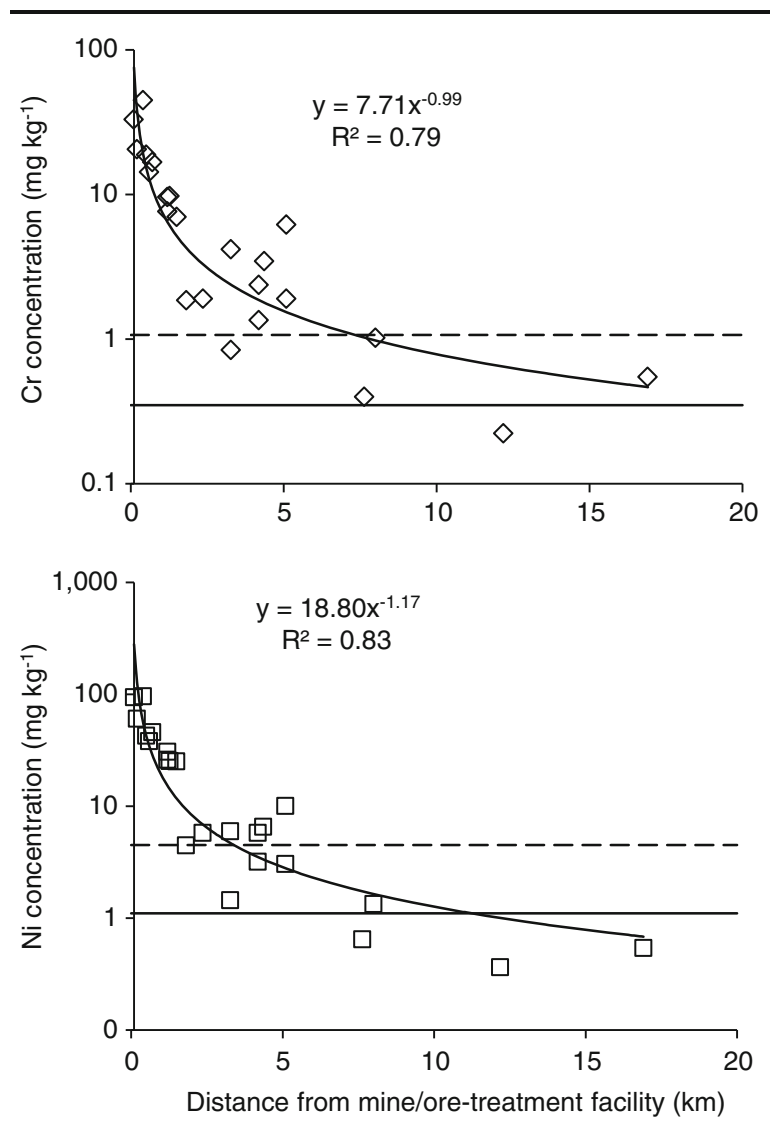

closest to the mine, station $\mathrm{C} 1$ and $\mathrm{C} 2(<1 \mathrm{~km}$ from mine; Fig. 1). No significant changes were observed for the other elements analysed. Concentrations of $\mathrm{Cr}$, $\mathrm{Ni}$ and $\mathrm{V}$ were measured up to 9.7, 16.7 and $1.4 \mathrm{mg}$ $\mathrm{kg}^{-1}$ dry wt., respectively. Pre-mining levels of $\mathrm{Cr}$, Ni and $\mathrm{V}$ in blue mussels were $1.4 \pm 0.8,2.7 \pm 0.9$ and 0.6 $\pm 0.4 \mathrm{mgkg}^{-1}$ dry wt., respectively. Thus, $\mathrm{Cr}$, Ni and $\mathrm{V}$ concentrations in blue mussels near the mine were elevated up to a factor of 7 for $\mathrm{Cr}, 6$ for $\mathrm{Ni}$ and 2 for V. Similarly to seaweeds, no significantly elevated concentrations of $\mathrm{Cr}$, Ni or $\mathrm{V}$ were observed in blue mussels in 2010 and 2011 after the mining activity ceased.

The dominant source for the observed contamination in seaweeds and blue mussels is considered an outwash of dissolved and particle-bound $\mathrm{Cr}, \mathrm{Ni}$ and $\mathrm{V}$ from land, originating from olivine ore dust dispersed during the mining process.

Fish and other samples

Element concentrations measured in fish liver from shorthorn sculpins before, during and after the mining period can be seen in Table 4. Shorthorn sculpins are relatively sedentary fish, and all fish were caught within an area $5 \mathrm{~km}$ from the mine. Fish liver is known to accumulate and concentrate contaminants such as metals (Johansen et al. 1991). However, no significant changes were observed in the element compositions in shorthorn sculpins after the mining started $(\mathrm{Cr}, \mathrm{Ni}$ and $\mathrm{V}$ were below or close to detection limits during the entire period).

Other samples that were collected near the mining area include freshwater samples from Long Lake (Fig. 1) and liver samples from Arctic char caught in Long Lake (Asmund et al. 2009; Søndergaard et al. 2009). None of these showed any significant changes in element composition as a result of the mining activity. in 2007 and 2009, and concentrations were up to $2.6 \mathrm{mg} \mathrm{Crkg}^{-1}$ dry wt. and $5.6 \mathrm{mg} \mathrm{Nikg}^{-1}$ dry wt. Pre-mining levels (mean $\pm \mathrm{SD}$ ) of $\mathrm{Cr}$ and $\mathrm{Ni}$ in seaweeds were $0.4 \pm 0.4$ and $2.3 \pm 1.2 \mathrm{mg} \mathrm{kg}^{-1}$ dry wt., respectively, and so concentrations were elevated up to a factor of 7 for $\mathrm{Cr}$ and 2 for $\mathrm{Ni}$. After the mining stopped in 2009, no significantly elevated concentrations of $\mathrm{Cr}$ and $\mathrm{Ni}$ were observed in seaweeds.

For blue mussels, significantly elevated concentrations of $\mathrm{Cr}$, Ni and $\mathrm{V}$ were observed at the two stations

\section{Conclusions}

This study investigated dispersal and bioaccumulation of elements related to an open-pit olivine mine at Seqi in Southwest Greenland. Studies using lichens, seaweeds, mussels and fish as biological indicator organisms showed that dispersion and bioaccumulation of especially $\mathrm{Cr}, \mathrm{Ni}, \mathrm{Co}$ and $\mathrm{Fe}$ as 
Fig. 3 Chromium (Cr) and nickel (Ni) concentrations in resident and transplanted $F$. nivalis lichens after 1 year of transplantation during the period from 2006 to 2011 . Points are mean values. Results are grouped according to the distances from the mine/ore treatment facility (0-1 and 1-5 km, respectively). Prior to transplantation, lichens had $\mathrm{Cr}$ and $\mathrm{Ni}$ concentrations of 0.2 $0.5 \mathrm{mgkg}^{-1}$ dry wt. for both metals. The solid horizontal lines represent the mean value of $\mathrm{Cr}$ and $\mathrm{Ni}$ for the entire monitoring area prior to mining observed in 2004 2005 (baseline). Dotted horizontal lines mark the upper $95 \%$ confidence interval of the baseline (2 SD from mean)
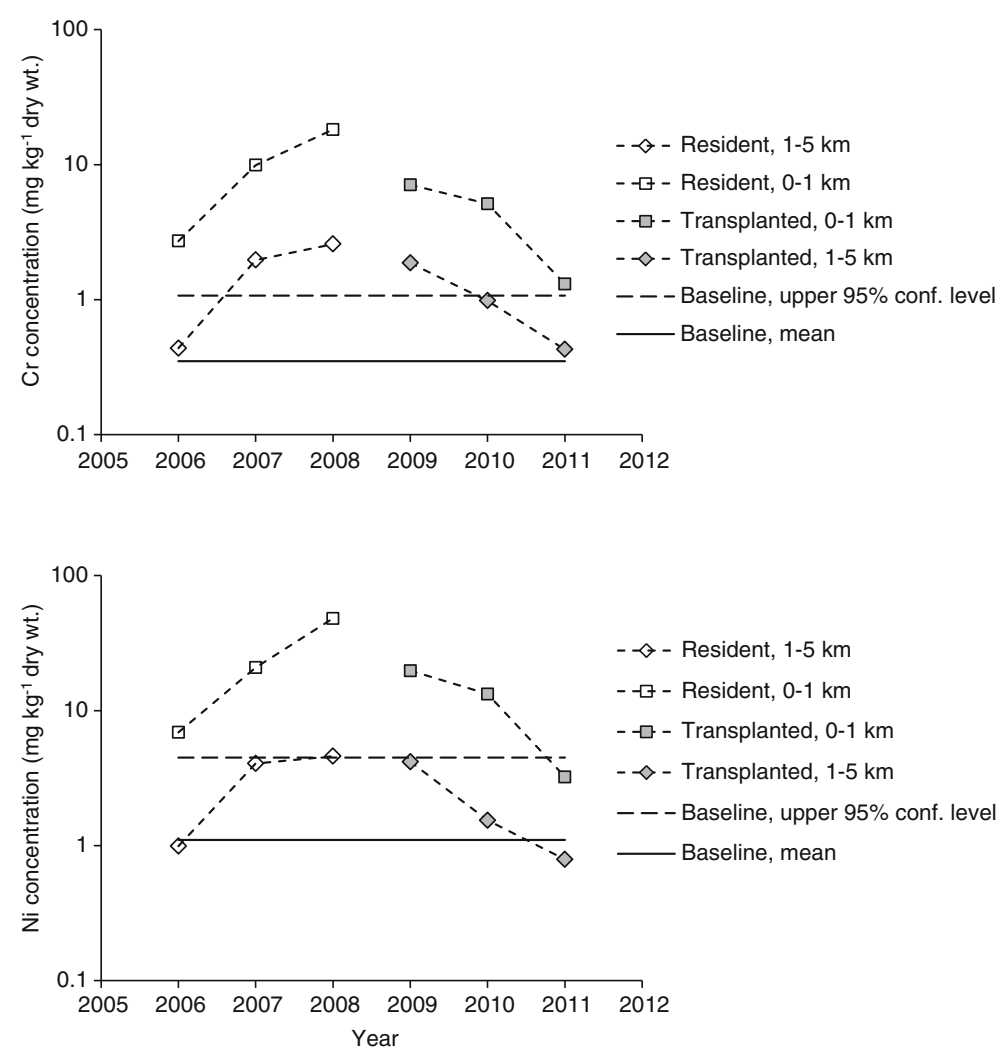

Table 2 Concentrations of selected elements in F. vesiculosus seaweeds at St. C1, located closed to the mine, sampled during the period from 2004 to 2011 (in milligram per kilogram dry wt.). Mean element concentrations and SD for seaweeds collected prior to mining in 2004-2005 are listed together with mean values for seaweeds at St. C1 from 2006 to 2011. Italicized values show elements that are significantly elevated in seaweeds at St. C1 after mining began $(t$ test; $p<0.05)$

\begin{tabular}{|c|c|c|c|c|c|c|c|c|}
\hline \multirow{3}{*}{$\begin{array}{l}\text { Year of sampling } \\
\text { Element }\end{array}$} & \multirow{2}{*}{\multicolumn{2}{|c|}{$\begin{array}{l}\text { Pre-mining period } \\
2004-2005\end{array}$}} & \multicolumn{4}{|c|}{ Mining period } & \multicolumn{2}{|c|}{ After mining } \\
\hline & & & \multirow{2}{*}{$\begin{array}{l}2006 \\
\text { Mean }\end{array}$} & \multirow{2}{*}{$\begin{array}{l}2007 \\
\text { Mean }\end{array}$} & \multirow{2}{*}{$\begin{array}{l}2008 \\
\text { Mean }\end{array}$} & \multirow{2}{*}{$\begin{array}{l}2009 \\
\text { Mean }\end{array}$} & \multirow{2}{*}{$\begin{array}{l}2010 \\
\text { Mean }\end{array}$} & \multirow{2}{*}{$\begin{array}{l}2011 \\
\text { Mean }\end{array}$} \\
\hline & Mean & SD & & & & & & \\
\hline $\mathrm{Li}$ & 0.45 & 0.22 & 0.30 & 0.43 & 0.29 & 0.40 & 0.57 & 0.35 \\
\hline $\mathrm{Mg}$ & 8,250 & 640 & 8,150 & 6,770 & - & - & - & - \\
\hline $\mathrm{Al}$ & 32 & 32 & 30 & 65 & 30 & 74 & 3 & 9 \\
\hline V & 0.40 & 0.34 & 0.33 & 0.47 & 0.31 & 0.53 & 0.16 & 0.17 \\
\hline $\mathrm{Cr}$ & 0.40 & 0.39 & 0.40 & 2.62 & 1.03 & 0.97 & 0.11 & 0.12 \\
\hline $\mathrm{Fe}$ & 69 & 73 & 79 & 181 & 94 & 197 & 36 & 38 \\
\hline $\mathrm{Ni}$ & 2.3 & 1.2 & 1.4 & 5.6 & 4.5 & 5.4 & 1.5 & 1.9 \\
\hline $\mathrm{Zn}$ & 12 & 4 & 13 & 16 & 10 & 17 & 13 & 14 \\
\hline Co & 0.59 & 0.34 & 0.35 & 0.77 & 0.66 & 0.67 & 0.25 & 0.46 \\
\hline $\mathrm{Cd}$ & 1.9 & 0.6 & 1.0 & 0.9 & - & - & - & - \\
\hline $\mathrm{Pb}$ & 0.051 & 0.030 & 0.026 & 0.040 & 0.025 & 0.066 & 0.046 & $<0.030$ \\
\hline
\end{tabular}

- indicates that the element was not determined 
Table 3 Concentrations of selected elements in M. edulis mussels at St. C1 and C2, located close to the mine, sampled during the period from 2004 to 2011 (in milligram per kilogram dry wt.). Mean element concentrations and SD for mussels collected prior to mining in 2004-2005 are listed together with mean values for mussels at St. C1 and C2 from 2006 to 2011. Italicized values show elements that are significantly elevated in mussels after mining began $(t$ test; $p<0.05)$

\begin{tabular}{|c|c|c|c|c|c|c|c|c|c|c|c|}
\hline \multirow[b]{2}{*}{ Year of sampling } & \multicolumn{2}{|c|}{ Pre-mining period } & \multicolumn{5}{|c|}{ Mining period } & & \multicolumn{3}{|c|}{ After mining } \\
\hline & 2004 & & 2006 & 2007 & 2008 & & 2009 & & 2010 & 2011 & \\
\hline Station & All & & $\mathrm{C} 1$ & $\mathrm{C} 1$ & $\mathrm{C} 1$ & $\mathrm{C} 2$ & $\mathrm{C} 1$ & $\mathrm{C} 2$ & $\mathrm{C} 2$ & $\mathrm{C} 1$ & $\mathrm{C} 2$ \\
\hline Distance from pier $(\mathrm{km})$ & $0-17$ & & $<1$ & $<1$ & $<1$ & $<1$ & $<1$ & $<1$ & $<1$ & $<1$ & $<1$ \\
\hline Element & Mean & $\mathrm{SD}$ & Mean & Mean & Mean & Mean & Mean & Mean & Mean & Mean & Mean \\
\hline $\mathrm{Li}$ & 0.76 & 0.31 & 0.62 & 0.70 & 0.47 & 0.66 & 0.87 & 0.73 & 0.86 & 0.51 & 0.45 \\
\hline $\mathrm{Mg}$ & 5,120 & 1,610 & 4,520 & 4,470 & - & - & - & - & - & - & - \\
\hline $\mathrm{Al}$ & 163 & 225 & 245 & 196 & 520 & 342 & 242 & 149 & 84 & 184 & 95 \\
\hline V & 0.59 & 0.36 & 0.81 & 1.17 & 0.70 & 0.58 & 1.40 & 1.05 & 0.65 & 1.06 & 1.07 \\
\hline $\mathrm{Cr}$ & 1.4 & 0.8 & 1.7 & 9.7 & 4.2 & 5.7 & 3.0 & 2.7 & 1.4 & 1.9 & 1.3 \\
\hline $\mathrm{Fe}$ & 206 & 173 & 325 & 541 & 277 & 241 & 409 & 242 & 157 & 259 & 170 \\
\hline $\mathrm{Ni}$ & 2.7 & 0.9 & 2.1 & 16.7 & 7.9 & 7.6 & 7.0 & 5.0 & 2.8 & 3.4 & 2.9 \\
\hline $\mathrm{Zn}$ & 77 & 23 & 63 & 69 & 64 & 83 & 97 & 91 & 79 & 93 & 85 \\
\hline Co & 0.47 & 0.23 & 0.36 & 1.03 & 0.52 & 0.59 & 0.68 & 0.56 & 0.44 & 0.55 & 0.52 \\
\hline $\mathrm{Cd}$ & 4.0 & 1.1 & 2.1 & 1.5 & - & - & - & - & - & - & - \\
\hline $\mathrm{Pb}$ & 0.38 & 0.13 & 0.62 & 0.55 & 0.47 & 0.33 & 0.71 & 0.36 & 0.29 & 0.65 & 0.31 \\
\hline
\end{tabular}

- indicates that the element was not determined

dust were the main environmental concern. These elements were associated with the olivine ore, and dominant sources of dispersion were blasting,

Table 4 Concentrations of selected elements in shorthorn sculpin liver sampled within $5 \mathrm{~km}$ from the mine during the period from 2004 to 2011 (in in milligram per kilogram wet wt.). Mean excavation and loading of ore material from the mining area, road traffic and ore crushing at the ore treatment facility. During the mining period,

\begin{tabular}{|c|c|c|c|c|c|c|c|}
\hline \multirow{3}{*}{$\begin{array}{l}\text { Year of sampling } \\
\text { Element }\end{array}$} & \multirow{2}{*}{\multicolumn{2}{|c|}{$\frac{\text { Pre-mining period }}{2004-2005}$}} & \multicolumn{4}{|c|}{ Mining period } & \multirow{3}{*}{$\begin{array}{l}\text { After mining } \\
2010 \\
\text { Mean }\end{array}$} \\
\hline & & & \multirow{2}{*}{$\begin{array}{l}2006 \\
\text { Mean }\end{array}$} & \multirow{2}{*}{$\begin{array}{l}2007 \\
\text { Mean }\end{array}$} & \multirow{2}{*}{$\begin{array}{l}2008 \\
\text { Mean }\end{array}$} & \multirow{2}{*}{$\begin{array}{l}2009 \\
\text { Mean }\end{array}$} & \\
\hline & Mean & SD & & & & & \\
\hline $\mathrm{Li}$ & $<0.02$ & - & $<0.02$ & $<0.02$ & $<0.01$ & $<0.01$ & $<0.02$ \\
\hline $\mathrm{Mg}$ & 169 & 20 & 167 & 136 & - & - & - \\
\hline $\mathrm{Al}$ & $<16$ & - & $<16$ & $<16$ & - & $<1$ & $<5$ \\
\hline V & 0.02 & 0.02 & 0.06 & 0.09 & 0.05 & $<0.01$ & $<0.06$ \\
\hline $\mathrm{Cr}$ & $<0.15$ & - & $<0.15$ & $<0.15$ & $<0.02$ & $<0.02$ & $<0.09$ \\
\hline $\mathrm{Fe}$ & 144 & 117 & 73 & 180 & 235 & 244 & 132 \\
\hline $\mathrm{Ni}$ & $<0.3$ & - & $<0.3$ & $<0.3$ & $<0.3$ & $<0.3$ & 0.08 \\
\hline $\mathrm{Zn}$ & 35 & 7 & 25 & 32 & - & 32 & 33 \\
\hline Co & 0.08 & 0.11 & 0.02 & 0.16 & 0.17 & 0.10 & 0.13 \\
\hline $\mathrm{Cd}$ & 0.37 & 0.25 & 0.28 & 0.60 & - & - & - \\
\hline $\mathrm{Pb}$ & $<0.03$ & - & $<0.03$ & $<0.03$ & $<0.01$ & $<0.01$ & $<0.04$ \\
\hline
\end{tabular}

- indicates that the element was not determined, < indicates a result below the limit of detection 
dust dispersion of mine-related elements was observed in distances up to $5 \mathrm{~km}$ from the mine. After mine closure, the dust dispersion decreased markedly, and 2 years after mine closure, dust dispersion could only be measured within $1 \mathrm{~km}$ from the mine/ore treatment facility. Highly elevated concentrations of mine-related elements could be observed on land in lichens, but only moderate changes in element compositions were observed in seaweeds and blue mussels in the marine environments. Furthermore, elevated element concentrations in seaweeds and mussels were only observed very locally near the mine and not after the mining activity ceased. This is in contrast to previous mining operations in Greenland (especially the $\mathrm{Pb}-\mathrm{Zn}$ mine in Maarmorilik and the cryolite mine in Ivittut) where significant contamination of the marine environment can still be measured decades after mine closure. In conclusion, the dispersal and bioaccumulation of elements from the olivine mine operation at Seqi was relatively low and is not considered to affect the adjacent marine ecosystem showing this to be a low-environmental-impact type of mining operation.

Acknowledgments The author wishes to thank Gert Asmund for chemical advice and for performing some of the chemical analyses, and Sigga Joensen and Lene Bruun for assistance in the field and in lab; all are from the Department of Bioscience, Aarhus University, in Roskilde. Also, the mining company Minelco A/S is thanked for providing the logical facilities on site.

\section{References}

Asmund, G., Boertmann, D., Johansen, P. (2009). Baseline and monitoring studies at the Seqi olivine mine 2004 to 2007. NERI Technical Report 715. National Environmental Research Institute (NERI), Aarhus University, 90 p. http:// www2.dmu.dk/Pub/FR715.pdf. Accessed 15 June 2012.

BMP (2009). Annual report 2008. Nuuk: Bureau of Minerals and Petroleum (BMP). http://www.bmp.gl/images/stories/ about_bmp/publications/annual_report_2008_high.pdf. Accessed 15 June 2012.

BMP (2010). Annual report 2009. Nuuk: Bureau of Minerals and Petroleum (BMP). http://www.bmp.gl/images/stories/ about_bmp/publications/annual_report_2009_high.pdf. Accessed 15 June 2012.

Carreras, H. A., \& Pignata, M. L. (2002). Biomonitoring of heavy metals and air quality in Cordoba City, Argentina using transplanted lichens. Environmental Pollution, 117, 77-87.

Gibb, J. O. T., Allen, J. R., \& Hawkins, S. J. (1996). The application of biomonitors for the assessment of minederived pollution on the West Coast of the Isle of Man. Marine Pollution Bulletin, 32(6), 513-519.

Glahder, C., Søndergaard, J., Asmund, G., Rigét, F. (2010). Environmental monitoring at the Nalunaq Gold Mine 2010. NERI Technical Report 811. National Environmental Research Institute (NERI), Aarhus University, 32 p. http://www2.dmu.dk/Pub/FR811.pdf. Access date 15 June 2012.

Johansen, P., Hansen, M. M., Asmund, G., \& Nielsen, P. B. (1991). Marine organisms as indicators of heavy metal pollution-experience from 16 years of monitoring at a lead-zinc mine in Greenland. Chemistry and Ecology, 5 (1-2), 35-55.

Johansen, P., Asmund, G., Rigét, F., Johansen, K., Schledermann, H. (2010). Environmental monitoring at the former lead-zinc mine in Maarmorilik, Northwest Greenland, in 2009. NERI Technical Report 775. National Environmental Research Institute (NERI), Aarhus University, 32 p. http://www2.dmu.dk/Pub/FR775.pdf. Accessed 15 June 2012.

Josefson, A. B., Hansen, J. L. S., Asmund, G., \& Johansen, P. (2008). Threshold response of benthic macrofauna integrity to metal contamination in West Greenland. Marine Pollution Bulletin, 56, 1265-1274.

Lackner, K. S. (2003). A guide to $\mathrm{CO}_{2}$ sequestration. Science, 300, 1677-1678.

Minelco (2012). http://www.minelco.com/en/Products-applications/ Products/Minelco-Olivine/. Accessed 15 June 2012.

Naeth, M. A., \& Wilkinson, S. R. (2008). Lichens as biomonitors of air quality around a iamond mine, Northwest Territories, Canada. Journal of Environmental Quality, 37, $1675-1684$.

Nash, T. H., III. (1996). Nutrients, elemental accumulation and cycling. In T. H. Nash III (Ed.), Lichen biology (pp. 136153). Cambridge: Cambridge University Press.

Priestley, E. (2004). Environmental due diligence desk study of the Seqi Olivine Project Greenland for Crew Development Corporation. Consultant Report, Voaden Sandbrook Limited, UK, 29 p.

Rainbow, P. S. (1995). Biomonitoring of heavy metal availability in the marine environment. Marine Pollution Bulletin, 31(4-12), 183-192.

Søndergaard, J., Asmund, G. (2010). Environmental monitoring at the Seqi olivine mine 2010. NERI Technical Report 813. National Environmental Research Institute (NERI), Aarhus University, 36 p. http://www2.dmu.dk/Pub/FR813.pdf. Accessed 15 June 2012.

Søndergaard, J., Schiedek, D., Asmund, G. (2009). Environmental monitoring at the Seqi olivine mine 20082009. NERI Technical Report 753. National Environmental Research Institute (NERI), Aarhus University, 48 p. http://www2.dmu.dk/Pub/FR753.pdf. Accessed 15 June 2012.

Søndergaard, J., Asmund, G., Johansen, P., \& Rigét, F. (2011). Long-term response of an arctic fiord system to lead-zinc mining and submarine disposal of mine waste (Maarmorilik, 
West Greenland). Marine Environmental Research, 71, 331341.

Søndergaard, J., Johansen, P., Asmund, G., \& Rigét, F. (2011). Trends of lead and zinc in resident and transplanted Flavocetraria nivalis lichens near a former lead-zinc mine in West Greenland. Science of the Total Environment, 409, 4063-4071.

Torres, M. A., Barros, M. P., Campos, S. C. G., Pinto, E., Rajamani, S., Sayre, R. T., et al. (2008). Biochemical biomarkers in algae and marine pollution: a review. Ecotoxicology and Environmental Safety, 71, 1-15.

Zimmer, L. A., Asmund, G., Johansen, P., Mortensen, J., \& Hansen, B. W. (2011). Pollution from mining in South Greenland: uptake and release of $\mathrm{Pb}$ by blue mussels (Mytilus edulis L.) documented by transplantation experiments. Polar Biology, 34, 431-439.

Zuo, G. (2006). Industrial applications of SeqiOlivine. Internal Report, Minelco, Sweden, 14 p. 